University of Nebraska - Lincoln

DigitalCommons@University of Nebraska - Lincoln

3-27-2007

\title{
Effect of backwashing on perchlorate removal in fixed bed biofilm reactors
}

Young Chul Choi

University of Illinois at Urbana-Champaign

Xu Li

University of Illinois at Urbana-Champaign

Lutgarde Raskin

University of Illinois at Urbana-Champaign

Eberhard Morgenroth

University of Illinois at Urbana-Champaign

Follow this and additional works at: https://digitalcommons.unl.edu/civilengfacpub

Part of the Civil Engineering Commons

Chul Choi, Young; Li, Xu; Raskin, Lutgarde; and Morgenroth, Eberhard, "Effect of backwashing on perchlorate removal in fixed bed biofilm reactors" (2007). Civil Engineering Faculty Publications. 26. https://digitalcommons.unl.edu/civilengfacpub/26

This Article is brought to you for free and open access by the Civil Engineering at DigitalCommons@University of Nebraska - Lincoln. It has been accepted for inclusion in Civil Engineering Faculty Publications by an authorized administrator of DigitalCommons@University of Nebraska - Lincoln. 


\title{
Effect of backwashing on perchlorate removal in fixed bed biofilm reactors
}

\author{
Young Chul Choi, ${ }^{\mathrm{a}, \mathrm{Xu} \mathrm{Li}}$, ${ }^{\mathrm{a}}$ Lutgarde Raskin, ${ }^{\mathrm{a}}$ and Eberhard Morgenroth, ${ }^{\mathrm{a}, \mathrm{b}}$ \\ a Department of Civil and Environmental Engineering, University of Illinois at Urbana-Champaign, Urbana, IL \\ 61801, USA \\ ${ }^{\mathrm{b}}$ Department of Animal Sciences, University of Illinois at Urbana-Champaign, Urbana, IL 61801, USA \\ Corresponding author - E. Morgenroth, Department of Civil and Environmental Engineering, University of Illinois at \\ Urbana-Champaign. 3219 Newmark Civil Engineering Laboratory, MC-250, 205 N. Mathews Ave., Urbana, IL 61801, \\ USA; tel 217 333-6965, fax 217 333-6968, email emorgenr@uiuc.edu \\ Y. C. Choi's current address: Department of Microbiology, University of Massachusetts Amherst, Amherst, MA 01003, USA \\ $X$. Li's current address: Department of Civil Engineering, University of Nebraska-Lincoln, Lincoln, NE 68588, USA \\ L. Raskin's current address: Department of Civil and Environmental Engineering, University of Michigan, 1351 Beal Ave.,
} Ann Arbor, MI 48109, USA

\begin{abstract}
The influence of backwashing on biological perchlorate reduction was evaluated in two laboratory scale fixed bed biofilm reactors using 1- or 3-mm glass beads as support media. Influent perchlorate concentrations were $50 \mu \mathrm{g} / \mathrm{L}$ and acetate was added as the electron donor at a concentration of $2 \mathrm{mg} \mathrm{C/L}$. Perchlorate removal was evaluated at various influent dissolved oxygen (DO) concentrations. Complete perchlorate removal was achieved with an influent DO concentration of $1 \mathrm{mg} / \mathrm{L}$ resulting in bulk phase DO concentrations below the detection limit of $0.01 \mathrm{mg} / \mathrm{L}$. The influence of increasing influent DO concentrations for $12 \mathrm{~h}$ periods was evaluated before and after individual backwash events. Partial perchlorate removal was achieved with an influent DO concentration of $3.5 \mathrm{mg} / \mathrm{L}$ before a strong backwash (bulk phase DO concentrations of approximately $0.2 \mathrm{mg} / \mathrm{L}$ ), while no perchlorate removal was observed after the strong backwash at the same influent DO level (bulk phase DO concentrations of approximately $0.8 \mathrm{mg} / \mathrm{L}$ ). The immediate effect of backwashing depended on influent DO concentrations. With influent DO concentrations of $1 \mathrm{mg} / \mathrm{L}$, strong backwashing resulted in a brief $(<12 \mathrm{~h})$ increase of effluent perchlorate concentrations up to $20 \mu \mathrm{g} / \mathrm{L}$; more pronounced effects were observed with influent DO concentrations of $3 \mathrm{mg} / \mathrm{L}$. Daily weak backwashing had a small and, over time, decreasing negative influence on perchlorate reduction, while daily strong backwashing ultimately resulted in the breakdown of perchlorate removal with influent DO concentrations of $3 \mathrm{mg} / \mathrm{L}$.
\end{abstract}

Keywords: perchlorate, fixed bed biofilm reactor, backwash, oxygen, competing electron acceptor

\section{Introduction}

Nine states in the US have recently defined state perchlorate advisory levels ranging from 1 to $18 \mu \mathrm{g} / \mathrm{L}$ for drinking water (USEPA, 2006). Several studies have shown that biological treatment is an effective technology to remove perchlorate from drinking water (Brown et al., 2002; Giblin et al., 2000; Herman and Frankenberger, 1999; Min et al., 2004). For example, for a typical groundwater concentra- tion of $50 \mu \mathrm{g} / \mathrm{L}$, biologically active carbon (BAC) fixed bed reactors consistently removed perchlorate to below $2 \mu \mathrm{g} / \mathrm{L}$ (Brown et al., 2002, 2005). Despite these encouraging studies, the reliability of biological drinking water treatment is sometimes questioned, in particular under dynamic loading conditions and during changes in reactor operation, such as after backwashing (Kim and Logan, 2001). The current study evaluates the influence of backwashing on perchlorate removal in fixed bed biofilm reactors. 
Regular backwashing is a key process for fixed bed biofilm reactors that is necessary to prevent clogging, to reduce excessive head loss across the filter, to maintain an active biofilm, to prevent the proliferation of filamentous bacteria and eukaryotic organisms, such as fungi and protozoa, and to enhance the mass transfer of contaminants to the biofilm (Brown et al., 2002; Hozalski and Bouwer, 1998; Laurent et al., 2003). However, backwashing also reduces the amount of active biomass in the reactor, which could potentially lead to unstable reactor performance (Lahav et al., 2001; Nakhla and Farooq, 2003). Optimal strategies for backwashing of biofilm reactors used for drinking water treatment are not well defined (Ahmad et al., 1998; Chaudhary et al., 2003; Laurent et al., 2003; Liu et al., 2001). For a perchlorate removing fluidized bed biofilm reactor, McCarty and Meyer (2005) demonstrated that, using a model based sensitivity analysis, biofilm detachment was a key factor influencing effluent perchlorate concentration. In their system, detachment was achieved by removing the most buoyant BAC particles from the top of the reactor, cleaning them externally, and then returning cleaned BAC into the fluidized bed. In fixed bed reactors the main process to remove biomass is backwashing by air scouring and filter bed expansion. Backwashing is typically performed in intervals ranging from 1 to 7 days (Boller et al., 1997). However, in some cases, backwashing intervals can be months (Brown et al., 2003). Backwashing intervals are usually determined by setting a fixed filter run time and a maximum head loss across the filter bed (Boller et al., 1997; Niquette et al., 1998). Using fixed bed reactors packed with plastic or sand media, Min et al. (2004) were able to reduce $77 \mu \mathrm{g} / \mathrm{L}$ perchlorate in groundwater to below $4 \mu \mathrm{g} / \mathrm{L}$. Regular weekly backwashing was necessary to prevent shortcircuiting, especially in their reactor packed using sand as a biofilm support medium. However, Kim and Logan (2000) observed that perchlorate removal in BAC reactors was not stable after backwashing. They suggested that perchlorate previously adsorbed to the granular activated carbon desorbed after backwashing, which caused fluctuating effluent perchlorate concentrations.

Evaluating the effect of backwashing on fixed bed biofilm reactor performance is complicated by the fact that backwashing influences a range of process conditions including fluid flow in the fixed bed, the amount of biomass, and biofilm structure. Biomass in fixed bed reactors is retained both in the form of biofilms attached to the surfaces of the support medium and in the form of large micro- bial aggregates that accumulate in the inter-particle space (Delahaye et al., 1999; Laurent et al., 2003). Backwashing removes the majority of the loosely attached, large microbial aggregates and a smaller fraction of the tightly attached biofilms (Servais et al., 1991). Mass transfer limitations of dissolved oxygen (DO) into large microbial aggregates reduce process efficiencies for aerobic processes (e.g., oxidation of organic carbon or nitrification) (Laurent et al., 1999, 2003). However, for perchlorate and nitrate removal, such microbial aggregates can be beneficial as DO mass transfer limitations can result in local anaerobic or anoxic zones allowing for perchlorate and nitrate reduction despite the presence of DO in the bulk phase. Kim et al. (2004) showed that oxygen and nitrate can be reduced simultaneously using a column reactor containing an aerobic and a denitrifying bacterial strain. Neither of these two populations were facultative aerobes and the bulk phase DO concentration was too high for denitrification to occur in the bulk liquid. They attributed their observation to the existence of anoxic zones allowing denitrifiers to reduce nitrate even when the bulk phase DO concentration was high. The impact of such mass transfer limitations on perchlorate removal in fixed bed reactors is not well understood.

The purpose of this study was to evaluate the influence of the frequency and intensity of backwash on perchlorate removal in biofilm reactors under varying influent DO levels for two fixed bed reactors with two different diameter glass beads (1 or $3 \mathrm{~mm}$ ) as biofilm support media. Responses of these biofilm reactors to increasing influent $\mathrm{DO}$ levels were monitored before and after individual backwash events. In addition, repeated daily backwash experiments were conducted with weak or strong backwashing.

\section{Materials and methods}

\subsection{Reactors and reactor operation}

Two laboratory-scale fixed bed column reactors with an inner diameter of $2.4 \mathrm{~cm}$ and a length of $14 \mathrm{~cm}$ were filled, respectively, with 1- and 3-mm diameter glass beads as packing materials and were operated in parallel. Physical parameters for both reactors are summarized in Table 1. The surface of the glass beads was etched for $1 \mathrm{~h}$ using $0.25 \% \mathrm{HF}$ to enhance the adhesion of bacteria. The influent flow was introduced in the bottom of the reactor at a rate of $2.7 \mathrm{~mL} / \mathrm{min}\left(Q_{\text {influent }}\right)$, resulting in an empty bed contact time of $23.4 \mathrm{~min}$. A recirculation loop $\left(Q_{\text {recirculation }}=\right.$

Table 1. Physical dimensions of the biofilm systems

\begin{tabular}{lcc}
\hline & 1-mm glass bead reactor & 3-mm glass bead reactor \\
\hline Empty bed volume $(\mathrm{mL})$ & 63.4 & 63.4 \\
Reactor volume occupied by the glass bead $(\mathrm{mL})$ & 38.7 & 37.0 \\
Measured porosity of the glass bead bed & 0.429 & 0.454 \\
Surface area of the reactor wall $\left(\mathrm{m}^{2}\right)$ & 0.011 & 0.011 \\
Surface area of the glass beads $\left(\mathrm{m}^{2}\right)$ & 0.133 & 0.040 \\
Total surface area $\left(\mathrm{m}^{2}\right)$ & 0.144 & 0.051 \\
\hline
\end{tabular}



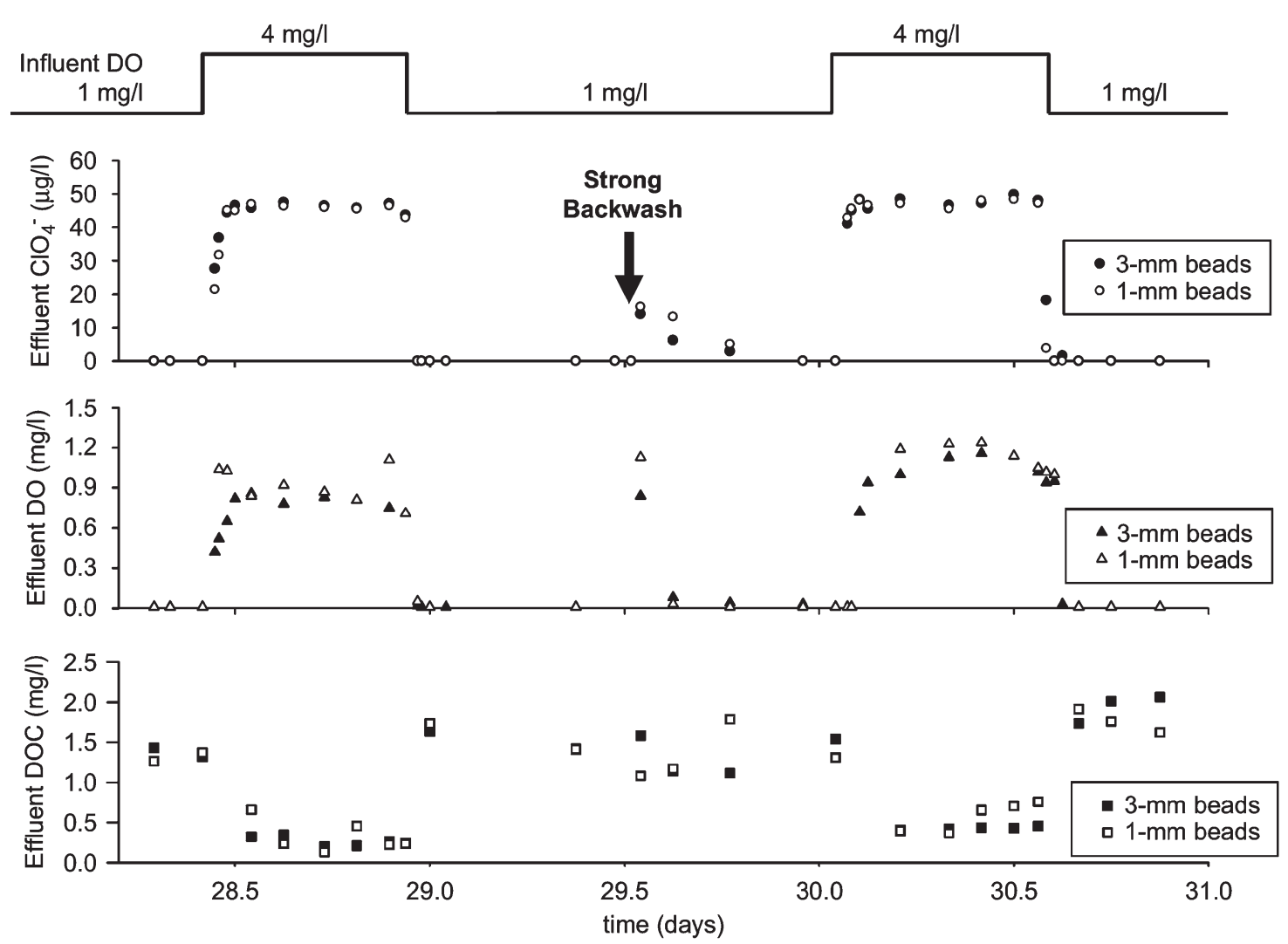

Figure 1. Reactor performance for 1-mm (open symbols) and 3-mm glass bead reactors (closed symbols) in response to increasing influent DO concentrations from 1 to $4 \mathrm{mg} / \mathrm{L}$ before and after backwash events.

$\left.5 \times Q_{\text {influent }}\right)$ was added to approximate completely mixed conditions of the bulk liquid. Flow distribution in the column may have been influenced to some extent by wall-effects with column to glass bead ratios of 24 and 8 for the 1 and 3-mm glass bead reactors, respectively (Cohen and Metzner, 1981). The 3-mm glass bead reactor was inoculated with biomass from a BAC filter previously operated with deionized, distilled water amended with $2 \mathrm{mg} \mathrm{C} / \mathrm{L} \mathrm{ac}-$ etate and $50 \mu \mathrm{g} / \mathrm{L}$ perchlorate (Brown et al., 2002) and then with groundwater amended with $50 \mu \mathrm{g} / \mathrm{L}$ perchlorate (Lin, 2004). The 1-mm glass bead reactor was inoculated with biomass collected from the 3-mm glass bead reactor which had been previously operated for 7 months.

Acetate was used as the sole electron donor at an influent concentration of $2 \mathrm{mg} \mathrm{C/L}$. The electron donor was delivered with a syringe pump and was mixed immediately before entering the reactor with a feed solution containing perchlorate and oxygen. The feed solution was prepared with deionized water and contained $50 \mu \mathrm{g} / \mathrm{L}$ perchlorate, $0.15 \mathrm{mg} \mathrm{N} / \mathrm{L} \mathrm{NH}_{4} \mathrm{Cl}$, and $0.5 \mathrm{mM}$ phosphate buffer resulting in $\mathrm{pH}$ 7.5. The influent DO level was adjusted to concentrations ranging from 1 to $4 \mathrm{mg} / \mathrm{L}$ by purging the feed solution with $\mathrm{N}_{2}$ gas. The feed solution was isolated from the atmosphere after purging using a floating cover to prevent oxygen transfer.

Both reactors were operated with a baseline influent DO level of $1 \mathrm{mg} / \mathrm{L}$ without backwashing for 4 weeks. The influent DO level was increased from 1 to $4 \mathrm{mg} / \mathrm{L}$ for a 12$\mathrm{h}$ period on day 28. A strong backwash (see below for de- tails) was performed on day 29, followed by another $12-\mathrm{h}$ period of operation with an influent DO level of $4 \mathrm{mg} / \mathrm{L}$ on day 30. The transient exposure to increased DO levels and backwashing was repeated with an influent DO concentration of $3.5 \mathrm{mg} / \mathrm{L}$, beginning on day 62. The effect of daily backwashing was evaluated after increasing the influent DO level to $3 \mathrm{mg} / \mathrm{L}$ on day 68. Five daily weak backwash events (starting on day 68) were followed by six daily strong backwash events (starting on day 73). After the period with daily strong backwash events, the reactors were monitored for 1 week without backwashing followed by another strong backwash on day 85. The influent DO level was reduced from 3 to $1 \mathrm{mg} / \mathrm{L}$ on day 102. Influent DO levels and timing of backwash events are schematically represented at the top of Figure 1 and Figures 3-6.

Backwashing was performed with two different intensities. A "weak backwash" was performed by placing the contents of the reactor into a $600-\mathrm{mL}$ beaker and adding $100 \mathrm{~mL}$ of previously collected effluent. The reactor contents were stirred for $1 \mathrm{~min}$ with a $7.5 \mathrm{~cm}$ long magnetic stir bar using a stir plate at 75 revolutions per minute (RPM). The supernatant containing the detached biomass was decanted. A "strong backwash" was performed by placing the contents of the reactor into a 600 -mL beaker, adding $125 \mathrm{~mL}$ of collected effluent, stirring at $150 \mathrm{RPM}$ for $1 \mathrm{~min}$, and decanting the supernatant containing the detached biomass. For the strong backwash, this process was repeated once. The biomass detached during backwashing was quantified as volatile suspended solids (VSS). 


\subsection{Analytical methods}

DO was measured using a galvanic oxygen sensor (WTW CellOx 325 with Oxi 340i, Weilheim, Germany) with a detection limit of $0.01 \mathrm{mg} / \mathrm{L}$ in a flow cell (WTW model D201, Weilheim, Germany) connected directly to the reactor effluent. Perchlorate was measured using an ion chromatograph (Dionex ICS-2000, Sunnyvale, CA, USA) with an AS50 autosampler and a conductivity detector. An AS16 column and an AG16 guard column were used and the detection limit was $1 \mu \mathrm{g} / \mathrm{L}$. The eluent was $65 \mathrm{mM} \mathrm{KOH}$ at a flow rate of $1.2 \mathrm{~mL} / \mathrm{min}$ and the injection volume was $990 \mu \mathrm{l}$. Dissolved organic carbon (DOC) was measured using a UV-Persulfate TOC Analyzer (Tekmar-Dohrmann Phoenix 8000, Mason, OH, USA) with a detection limit of $0.2 \mathrm{mg} / \mathrm{L}$ as C. All samples were filtered using a $0.45 \mu \mathrm{m}$ filter (Nalgene SFCA $25 \mathrm{~mm}$, Nalge Nunc International, Rochester, NY, USA) prior to analysis. VSS were measured according to Standard Methods (APHA et al., 1999). A stereomicroscope (Zeiss Stemi 2000-C, Oberkochen, Germany) was used to image the biofilm growth patterns directly through the glass wall of the reactors without disturbing the biomass structure.

\section{Results}

\subsection{Influent DO variations and individual backwash events}

During the initial baseline operation with an influent DO level of $1 \mathrm{mg} / \mathrm{L}$, effluent perchlorate concentrations for both reactors were consistently below the detection limit of $1 \mu \mathrm{g} / \mathrm{L}$ (days 0-28). When the influent DO level was increased to $4 \mathrm{mg} / \mathrm{L}$ for a period of $12 \mathrm{~h}$ on day 28, perchlorate removal immediately ceased and effluent perchlorate concentrations increased to $50 \mu \mathrm{g} / \mathrm{L}$ (Figure 1). During that period, effluent DO concentrations increased from below the detection limit of $0.01 \mathrm{mg} / \mathrm{L}$ to approximately $1 \mathrm{mg} / \mathrm{L}$ and effluent DOC concentrations decreased from approximately 1.5 to below $0.5 \mathrm{mg} \mathrm{C} / \mathrm{L}$ in both reactors (Figure 1). Based on the observed DOC removal $(2 \mathrm{mg} \mathrm{C} / \mathrm{L}=5.33 \mathrm{mg}$ $\mathrm{COD} / \mathrm{L})$ and DO removal $(3.2 \mathrm{mg} / \mathrm{L})$, a net yield $\left(Y_{\mathrm{H}}\right)$ of $0.4 \mathrm{~g} \mathrm{COD}_{\text {biomass }} / \mathrm{g} \mathrm{COD}_{\text {acetate }}$ can be calculated assuming that all acetate in the influent was metabolized and that the DOC in the effluent only consisted of soluble microbial products. This observed net yield is reasonable for heterotrophic growth (Henze et al., 2002). With relatively high bulk phase (=effluent) DO concentrations of approximately $1 \mathrm{mg} / \mathrm{L}$, mass transfer limited anaerobic zones were likely not present, explaining the absence of perchlorate removal during this $12-\mathrm{h}$ period of increased influent DO concentrations. As soon as the influent DO level was returned to baseline conditions, both reactors removed perchlorate completely (Figure 1).

A strong backwash was performed $12 \mathrm{~h}$ after the end of the period with increased influent DO concentrations (Figure 1). Immediately following the backwash event, the effluent perchlorate concentrations increased to approximately $15 \mu \mathrm{g} / \mathrm{L}$ in both reactors followed by a complete recovery of perchlorate removal within $12 \mathrm{~h}$. On day 30 (12 h after the backwash event), the influent DO level was increased again to $4 \mathrm{mg} / \mathrm{L}$ for a period of $12 \mathrm{~h}$. Similar to the previous results, effluent perchlorate concentrations reached almost $50 \mu \mathrm{g} / \mathrm{L}$, effluent DO concentrations increased, and DOC concentrations decreased in both reactors. However, both DO and DOC concentrations were slightly higher than during the previous period with the same $4 \mathrm{mg} / \mathrm{L}$ influent DO levels, suggesting that, after backwashing, aerobic acetate oxidation was biomass limited. As soon as baseline operation was resumed, again, both reactors removed perchlorate completely.

In this study, glass beads were selected as the support medium for biofilm growth, instead of a sorptive material such as granular activated carbon, to allow evaluation of the effect of biomass growth and detachment patterns without interference from sorption or desorption of perchlorate and oxygen. The amounts of biomass detached during backwashing on day 29 were 28.3 and $18.8 \mathrm{mg}$ VSS for the 1 - and 3-mm glass bead reactors, respectively. The reactors had been operated for 4 weeks without backwashing prior to backwashing on day 29. Assuming an average effluent acetate concentration of $1.5 \mathrm{mg} \mathrm{C} / \mathrm{L}$ during baseline operation with an influent DO level of $1 \mathrm{mg} / \mathrm{L}$ and a net yield of $0.4 \mathrm{~g}$ $\mathrm{COD}_{\text {biomass }} / \mathrm{g} \mathrm{COD}_{\text {acetate }}$ the estimated biomass production for this 4 -week period is $41 \mathrm{mg}$ VSS. The amount of biomass removed during the backwashing accounted for $69 \%$ and $46 \%$ of the estimated biomass production during this period in the 1- and 3-mm glass bead reactors, respectively. However, backwash efficiencies vary and the amount of VSS removed in a single backwash event may be smaller or larger than the net biomass accumulation between backwash events. In addition, biomass may have been lost through detachment during normal operation. The larger amount of biomass removed in the 1-mm glass bead reactor suggests that more biomass accumulated in the 1-mm glass bead reactor, which can be attributed to a larger surface area and an improved ability to retain biomass during normal operation compared to the 3-mm glass bead reactor.

Accumulation of large biomass aggregates in the size range of several hundred micrometers was observed during operation in both reactors (Figure 2), but they were removed during backwash events. While a quantitative analysis of size and amount of aggregates was beyond the scope of this study, this qualitative observation supports the feasibility of localized mass transport limited zones allowing for perchlorate removal to occur in the reactors in spite of increased bulk phase DO concentrations.
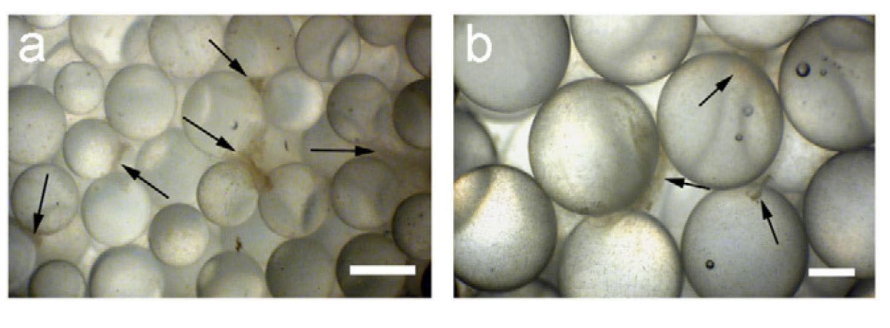

Figure 2. Stereomicroscope image of media from the 1-mm (a) and 3-mm (b) glass bead reactor. Arrows indicate large microbial aggregates. Scale bars denote $1 \mathrm{~mm}$. 

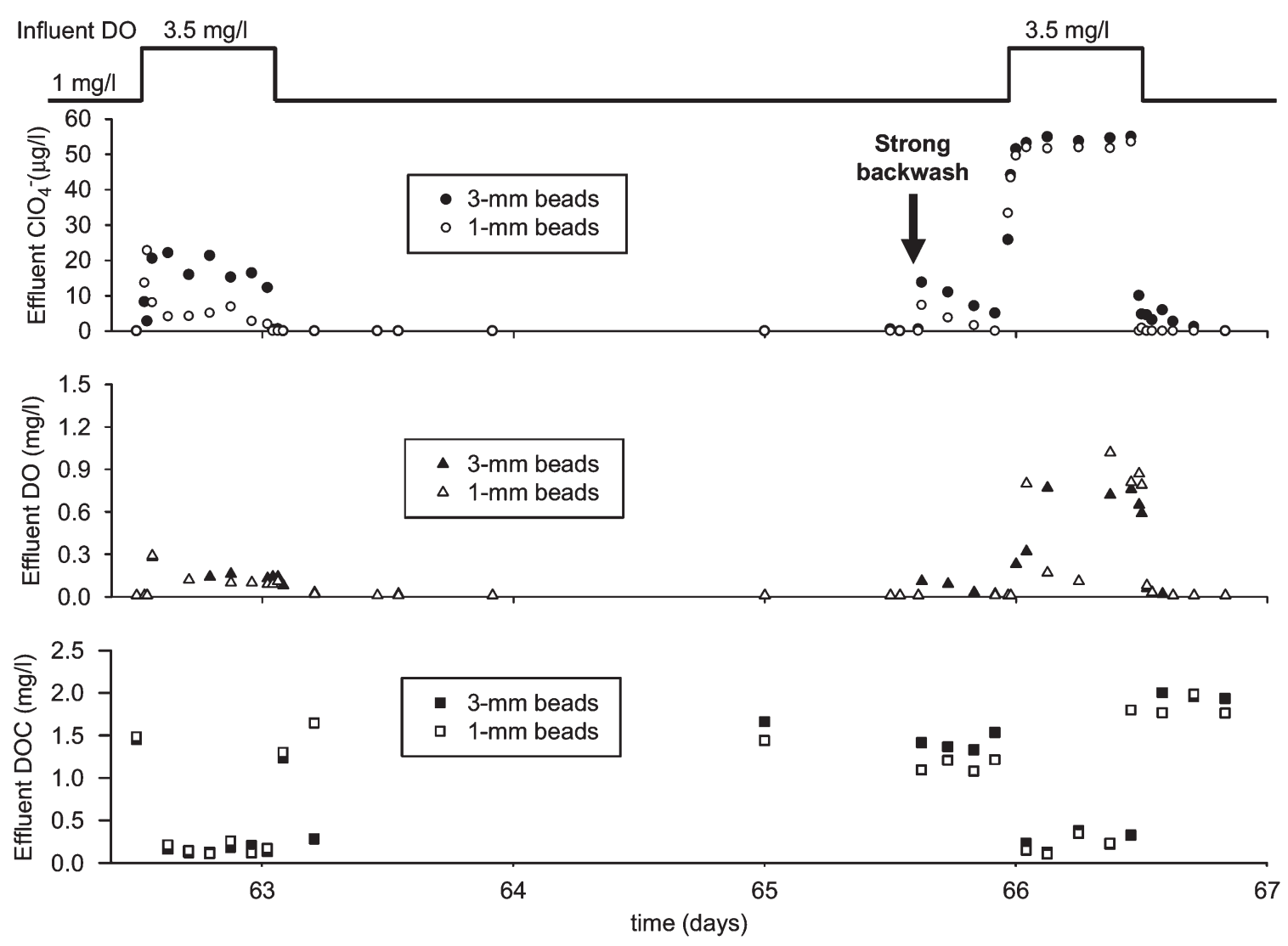

Figure 3. Reactor performance for 1-mm (open symbols) and 3-mm glass bead reactors (closed symbols) in response to increasing influent DO concentrations from 1 to $3.5 \mathrm{mg} / \mathrm{L}$ before and after backwash events.

The next experimental phase evaluated the influence of short-term increases of influent DO levels to $3.5 \mathrm{mg} /$ L, which is only slightly higher than the estimated DO concentration of $3.2 \mathrm{mg} / \mathrm{L}$ required to completely oxidize the $2 \mathrm{mg} \mathrm{C} / \mathrm{L}$ of acetate present in the influent. Unlike the previous experiment, the response of the reactors during 12-h periods with an influent DO level of $3.5 \mathrm{mg} /$ $\mathrm{L}$ was substantially different before and after backwashing (Figure 3). During the first 12-h period (before backwashing), effluent perchlorate concentrations temporarily increased to 5 and $20 \mu \mathrm{g} / \mathrm{L}$ in the 1 - and 3-mm glass bead reactors, respectively. During the second 12 -h period (after backwashing), effluent perchlorate concentrations increased to the influent level of $50 \mu \mathrm{g} / \mathrm{L}$ in both reactors. Bulk phase DO concentrations increased to approximately $0.2 \mathrm{mg} / \mathrm{L}$ in the first and approximately $0.8 \mathrm{mg} / \mathrm{L}$ during the second $12-\mathrm{h}$ period. Bulk phase DOC concentrations decreased in both periods to approximately $0.2 \mathrm{mg} \mathrm{C} / \mathrm{L}$. The immediate effect of backwashing under baseline conditions (day 65) was similar to the effect observed for the previous backwash and the effluent perchlorate concentrations temporarily increased to 7.3 and $13.7 \mu \mathrm{g} / \mathrm{L}$ in the 1 - and 3-mm glass bead reactors, respectively. The amounts of VSS removed during this second backwash event were 58 and $37.5 \mathrm{mg}$ VSS for the 1- and 3-mm glass bead reactors, respectively. The amount of removed VSS is close to the theoretically ex- pected amount of $53 \mathrm{mg}$ VSS (assuming an average effluent acetate concentration of $1.5 \mathrm{mg} \mathrm{C/L}$ for the 36 days of operation since the previous backwash).

\subsection{Daily backwash events}

The effect of daily backwashing was evaluated with an influent DO level of $3 \mathrm{mg} / \mathrm{L}$, which is just below the theoretical stoichiometric requirement for the complete oxidation of the acetate present in the influent. Increasing the influent DO concentration from 1 to $3 \mathrm{mg} / \mathrm{L}$ did not result in increased effluent perchlorate concentrations (day 68, before backwashing in Figure 4). Effluent perchlorate concentrations increased following each of five weak backwash events. In the 1-mm glass bead reactor, effluent perchlorate concentrations decreased to below the detection limit within $24 \mathrm{~h}$, while the recovery in the 3-mm glass bead reactor remained incomplete after the first three backwashes. Daily weak backwashing prevented large microbial aggregates from developing in both glass bead reactors based on visual examination of biomass removed during backwash events and of the filter beds. Over time, backwashing had less influence on perchlorate removal in both reactors: the initial weak backwashing caused effluent perchlorate concentrations to increase up to $30 \mu \mathrm{g} / \mathrm{L}$ while perchlorate concentrations after subsequent backwash events remained below $10 \mu \mathrm{g} / \mathrm{L}$ at all times. 

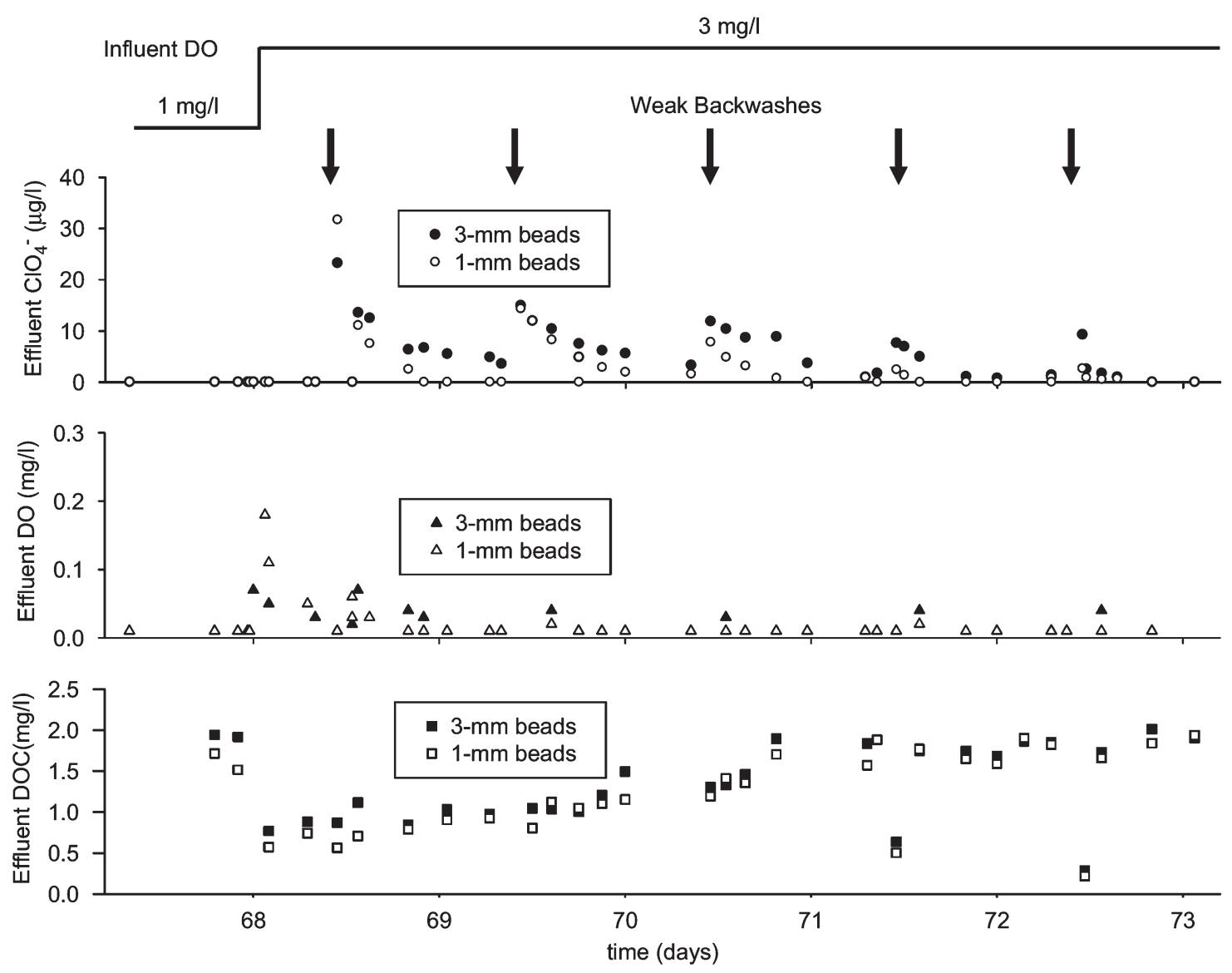

Figure 4. Reactor performance for 1-mm (open symbols) and 3-mm glass bead reactors (closed symbols) in response to weak daily backwash events with influent DO concentrations of $3 \mathrm{mg} / \mathrm{L}$.

Daily strong backwashing began on day 73 and had a much larger impact on perchlorate removal compared to weak backwashing (Figure 5). Following five strong backwashing events, effluent perchlorate concentrations in both reactors increased to $50 \mu \mathrm{g} / \mathrm{L}$ and only decreased slowly. In most cases, effluent perchlorate concentrations did not decrease below the detection limit between daily strong backwash events. During the period of daily strong backwashing, effluent DO concentrations were approximately $0.5 \mathrm{mg} / \mathrm{L}$; the effluent DOC concentrations did not show a clear pattern. Lack of perchlorate removal after strong backwashing can be explained by the loss of large biomass aggregates, removal of biofilm growing on the glass bead surface, and increased bulk phase DO concentrations due to biomass limited oxygen removal. Unlike the weak daily backwashing experiment, there was no substantial difference between the performances of 1- and 3-mm glass bead reactors.

\subsection{Recovery of system performance after strong daily backwashing}

After the five daily strong backwashing events, while maintaining an influent DO level of $3 \mathrm{mg} / \mathrm{L}$, perchlorate removal continued to deteriorate (Figure 6). On day 85, following six strong backwashing events, the effluent perchlo- rate concentrations reached approximately $20 \mu \mathrm{g} / \mathrm{L}$ in both reactors. Perchlorate removal deteriorated further after another strong backwashing event on day 85 even though bulk phase DO concentrations were at times below $0.1 \mathrm{mg} /$ L. Apparently, daily strong backwashing resulted in a substantial decrease in the activity of perchlorate reducing bacteria in the systems. Perchlorate reduction could not be reestablished with an influent DO level of $3 \mathrm{mg} / \mathrm{L}$ during a 2-week period without backwashing even though these conditions prior to daily backwashing had allowed for stable and complete perchlorate removal.

After decreasing influent DO levels to $1 \mathrm{mg} / \mathrm{L}$ on day 102 , bulk phase DO concentrations decreased to below the detection limit and perchlorate removal recovered completely within 2 or 4 days for the 1- and 3-mm glass bead reactors, respectively. During this period, effluent DOC levels increased above influent acetate concentrations, possibly due to an increased release of soluble microbial products after decreasing the influent DO levels to $1 \mathrm{mg} / \mathrm{L}$. The time period necessary for the recovery of perchlorate removal was longer than the time required for system recovery after short-term exposure to increased influent DO levels, but shorter than the time required for initial reactor start-up of 2 weeks (data not shown). The time required for recovery can be explained by the need for regrowth of perchlorate reducing bacteria. The faster recovery of the 1- 


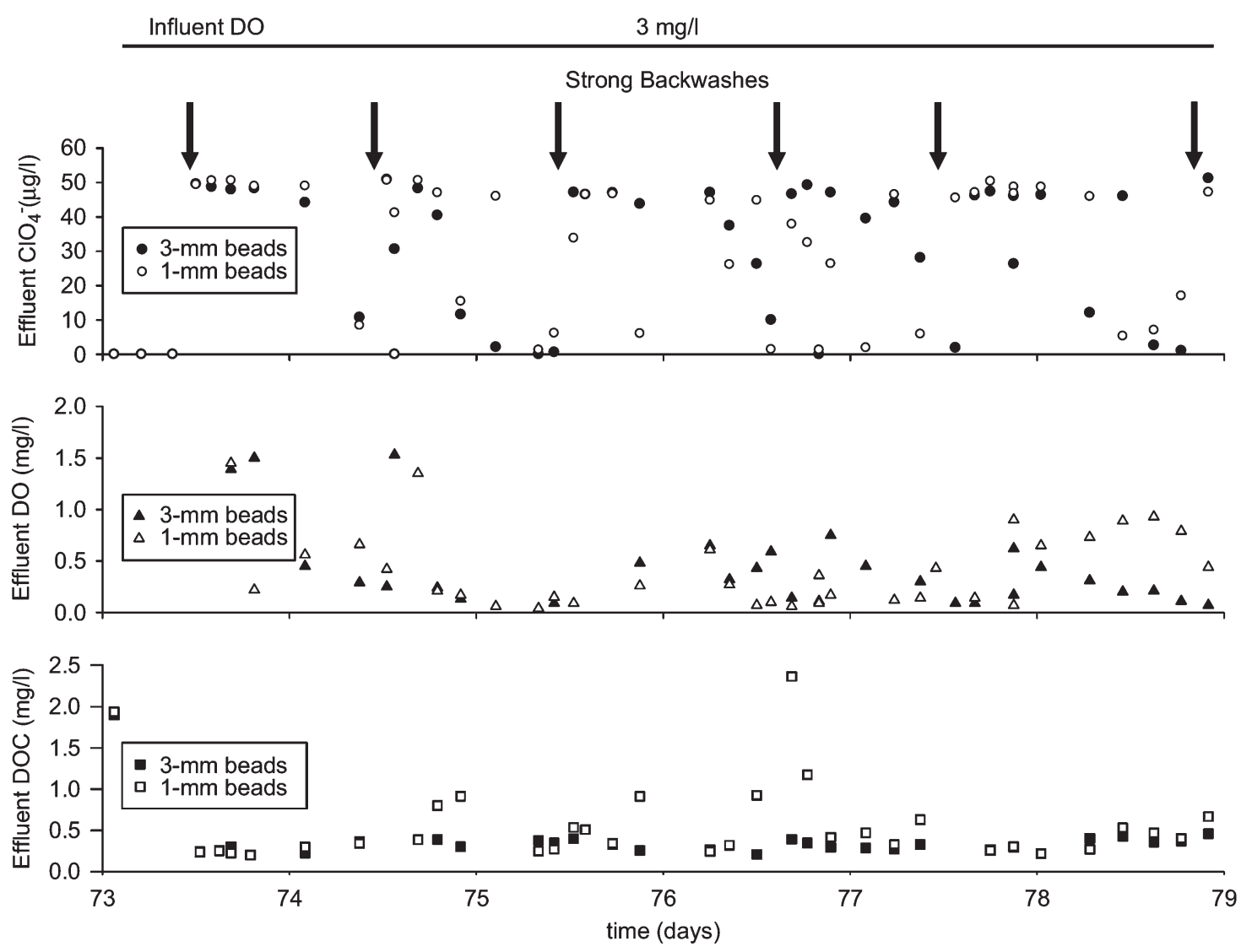

Figure 5. Reactor performance for 1-mm (open symbols) and 3-mm glass bead reactors (closed symbols) in response to strong daily backwash events with influent DO concentrations of $3 \mathrm{mg} / \mathrm{L}$.

mm compared to the 3-mm glass bead reactor is consistent with the larger surface area in the 1-mm glass bead reactor, which may have retained a larger amount of perchlorate reducing bacteria even during the period of reduced perchlorate removal.

\section{Discussion}

\subsection{Influence of oxygen}

Perchlorate reduction is inhibited by oxygen for all known perchlorate reducing bacteria (Kengen et al., 1999; Song and Logan, 2004; Xu et al., 2003). Inhibition by oxygen also was observed in the current study; an influent DO level of $4 \mathrm{mg} / \mathrm{L}$ resulted in bulk phase DO concentrations of approximately $1 \mathrm{mg} / \mathrm{L}$ and the breakdown of perchlorate removal (Figure 1). However, for an influent DO level of $3.5 \mathrm{mg} / \mathrm{L}$, bulk phase DO concentrations were approximately $0.2 \mathrm{mg} / \mathrm{L}$ (following a period of more than 4 weeks without backwashing) and with these conditions partial perchlorate removal was observed (day 62 in Figure 3). The effect of oxygen on perchlorate removal observed in this study is different from previously reported observations. Song (2004) determined a threshold DO concentration to inhibit perchlorate reduction of $0.04 \mathrm{mg} / \mathrm{L}$ (only $4 \%$ of the influent perchlorate was reduced in a chemostat by a pure suspended culture of Dechlorosoma sp. KJ). Song and Logan
(2004) showed that a 12-h exposure to DO concentrations of 6-7 mg/L inhibited perchlorate removal in a suspended culture of Dechlorosoma sp. KJ even after oxygen had been removed. In the current study, while no perchlorate removal was achieved with influent DO levels of $4 \mathrm{mg} / \mathrm{L}$ (bulk phase DO concentrations of approximately $1 \mathrm{mg} / \mathrm{L}$ ), complete perchlorate removal was achieved within $30 \mathrm{~min}$ after decreasing the influent DO concentrations to $1 \mathrm{mg} /$ $\mathrm{L}$ (bulk phase DO concentrations below the detection limit of $0.01 \mathrm{mg} / \mathrm{L}$ ) (Figure 1). There are two possible explanations for these differences: (1) inhibition threshold levels and long-term effects of oxygen are species dependent and differ between Dechlorosoma sp. KJ and the perchlorate reducing bacteria present in the mixed community in the current study; (2) mass transfer limitations in the current study caused the DO concentrations inside the biofilm to be substantially lower than in the bulk phase. The relevance of mass transfer limitations due to the accumulation of biomass has been well documented for BAC filters (Laurent et al., 2003). With bulk phase DO concentrations of $0.2 \mathrm{mg} / \mathrm{L}$ (day 62, Figure 3), DO concentrations in part of the biofilm conceivably were below the $0.04 \mathrm{mg} / \mathrm{L}$ threshold reported by Song (2004). It is interesting to note that on day 62, with an influent DO level of $3.5 \mathrm{mg} / \mathrm{L}$, perchlorate removal was greater in the 1-mm glass bead reactor compared to the removal in the 3-mm glass bead reactor even though the bulk phase DO and DOC were very similar. This result can be 

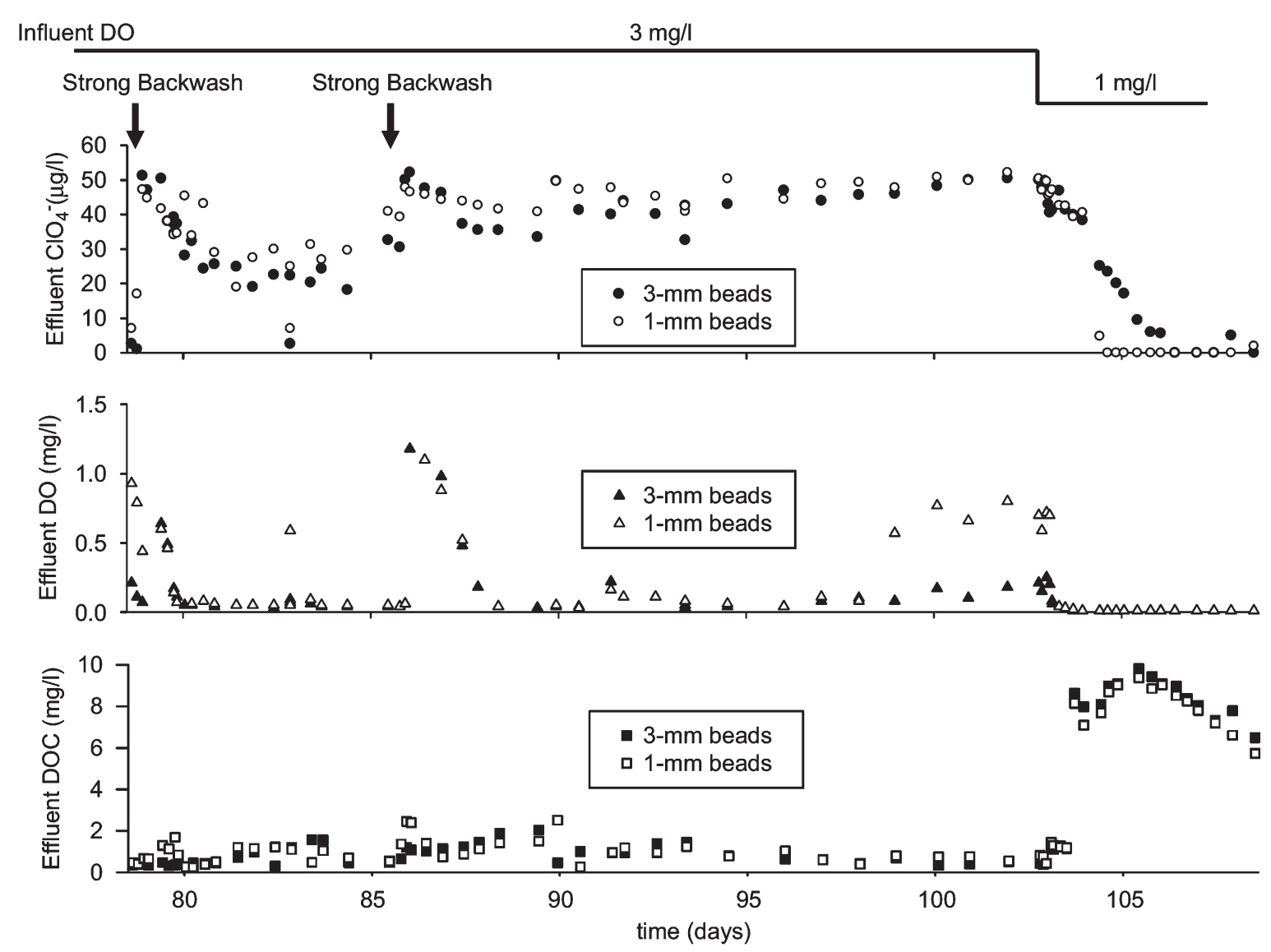

Figure 6. Reactor performance for 1-mm (open symbols) and 3-mm glass bead reactors (closed symbols) following a period of strong daily backwashing with influent DO concentrations of 3 or $1 \mathrm{mg} / \mathrm{L}$.

explained since the 1-mm glass bead reactor had accumulated more biomass compared to the 3-mm glass bead reactor (based on 58 vs. $37.5 \mathrm{mg}$ VSS that were removed during backwashing, respectively) and presumably a larger fraction of the biomass was anaerobic. This apparent beneficial effect of mass transfer limitations was observed only for relatively low bulk phase DO concentrations of less than $0.2 \mathrm{mg} / \mathrm{L}$. In a deep biofilm anaerobic zones can develop if the biofilm is sufficiently thick and if electron acceptor concentrations relative to electron acceptor concentrations are sufficiently high (Wanner et al., 2006). Oxygen is likely to be limiting for $\gamma \gg 1$ where

$$
r=\left(1-\mathrm{Y}_{\mathrm{H}}\right) D_{\mathrm{S}} / D_{\mathrm{O}_{2}} \times S_{\mathrm{S}} / S_{\mathrm{O}_{2}}
$$

and where $D_{\mathrm{S}}$ and $D_{\mathrm{O}_{2}}$ are diffusion coefficients for the electron donor and oxygen in the biofilm and $S_{\mathrm{S}}$ and $S_{\mathrm{O}_{2}}$ are bulk phase electron donor and DO concentrations. For bulk phase DO concentrations of approximately $0.2 \mathrm{mg} / \mathrm{L}$, anaerobic zones are likely to develop for bulk phase acetate concentrations larger than $0.27 \mathrm{mg}$ DOC/L (assuming $D_{\mathrm{S}}$ and $D_{\mathrm{O} 2}$ of 0.8 and $1.7 \mathrm{~cm}^{2} / \mathrm{d}$, respectively). Thus, it is feasible that oxygen utilization in the biofilm resulted in anaerobic zones. Problems with the direct application of Equation (1) to the experimental results in this study are that the effluent DOC most likely accounts for a mixture of organic substrates including non-biodegradable soluble microbial products and that Equation (1) does not take into account endogenous respiration. For an influent DO level of $4 \mathrm{mg} /$ L (bulk phase DO concentrations of approximately $1 \mathrm{mg} /$ L), mass transfer limitations were apparently not sufficient to reduce DO concentrations within the biofilm to below the inhibitory threshold (Figure 1).

\subsection{Influence of backwashing}

The short-term effect of backwashing on perchlorate removal depended both on influent DO levels and backwash intensity. With an influent DO level of $1 \mathrm{mg} / \mathrm{L}$, a time period of up to $12 \mathrm{~h}$ was required for the effluent perchlorate concentration to decrease to below the detection limit following a backwashing event (Figure $1 \&$ Figure 3). This lag period was longer than the lags observed after shortterm increases of influent DO levels, which were typically less than $1 \mathrm{~h}$. Since exposure of biomass from the reactors to DO concentrations of up to $40 \mathrm{mg} / \mathrm{L}$ did not result in a lag in perchlorate reduction (data not shown), short-term exposures to the atmosphere during backwashing should not have had an impact on the length of the lag period after backwashing. One explanation for the observed lag could be that some biomass growth was required before complete perchlorate removal could be achieved after backwashing. 
With an influent DO concentration of $3 \mathrm{mg} / \mathrm{L}$, the recovery of perchlorate removal after backwashing was even slower. For a single weak backwash, partial perchlorate reduction recovered within approximately $12 \mathrm{~h}$ (day 68 in Figure 4), while after strong backwashing full recovery was not achieved within $24 \mathrm{~h}$ (day 73 in Figure 5). This difference between observed perchlorate removal after weak or strong backwash could be explained by the weak backwash removing mainly loosely attached large microbial aggregates while the strong backwash also removes significant amounts of the strongly attached biofilm. As suggested above, perchlorate reduction in the presence of detectable bulk phase DO concentrations can be achieved in localized anaerobic zones within large microbial aggregates. Removing these aggregates has a larger effect on perchlorate removal for higher bulk phase DO concentrations. With an influent DO level of $1 \mathrm{mg} / \mathrm{L}$, bulk phase DO concentrations were below the detection limit and mass transfer resistance may not be necessary to provide conditions suitable for perchlorate reduction. Brown et al. (2003) reported a different effect of backwashing on perchlorate removal. They observed improved perchlorate removal following backwashing presumably due to reduced clogging and channeling following months of operation without backwashing. In the current study, backwashing never resulted in improved system performance.

In full-scale fixed bed biofilm reactors backwashing intervals are typically much shorter (ranging from 1 to 7 days) than in most research studies. However, backwashing is costly as it causes downtime of the reactors during backwashing and since the wash water needs to be treated. Results from this and other laboratory scale studies (e.g., Brown et al., 2003) indicate that longer intervals between backwashing can be feasible, at least if biological performance is the criterion used for evaluation. In full-scale reactors, shorter intervals between backwashing are often based on process requirements other than the biological performance (e.g., backwashing is performed to prevent localized lumping of filter medium or to distribute active biomass evenly over the height of the reactors). The feasibility of longer backwashing intervals between backwashing for fixed bed biofilm reactors used for drinking water treatment should be further evaluated in pilot or full-scale applications.

The positive effect of localized anaerobic zones on perchlorate reduction was observed only for a narrow range of influent DO levels, while influent DO and electron donor were present in approximately stoichiometric ratios resulting in $\gamma \approx 1$. Brown et al. (2005) suggested dosing electron donor at approximately stoichiometric requirements to reduce competing electron acceptors in the influent.* In research applications, however, electron donor is often added

\footnotetext{
* Note that Brown et al. (2005) expressed their acetate dosage as the amount of acetate needed to reduce influent electron acceptors but neglected acetate used for cell synthesis. Taking into account cell synthesis with a net yield of $0.4 \mathrm{~g} \mathrm{COD}_{\text {biomass }} / \mathrm{g} \mathrm{CO}$ $\mathrm{D}_{\text {acetate }}$ the acetate dosing of $150-183 \%$ of the stoichiometric requirement in their paper corresponds to $90-110 \%$ of the actual stoichiometric requirement.
}

in much larger concentrations (Brown et al., 2003; Min et al., 2004). It should be noted that conclusions drawn on the influence of backwashing are applicable only when similar electron donor and acceptor ratios are considered. For practical reactor operation, one goal is to minimize electron donor addition in order to minimize cost. While it is possible to achieve stable performance by adding near-stoichiometric amounts of electron donor, it needs to be considered that minimizing electron donor addition can result in less stable system performance following backwashing.

\subsection{Influence of biofilm history}

Perchlorate removal depended not only on influent DO and electron donor concentrations but also on the history of the reactor. For daily weak backwashing, the system adjusted to these frequent backwashes after some time. The weak backwash events on days 71 and 72 had a much smaller impact on perchlorate removal than those performed on days 68, 69, and 70 (Figure 4). This observation may be explained by the development of tightly attached biofilms of perchlorate reducing and other heterotrophic bacteria on the support medium, and the reduced role of loosely attached large aggregates that are easily removed during backwashing. For daily strong backwashing, however, perchlorate removal deteriorated and did not recover even after 17 days without backwashing with influent and operating conditions that had previously allowed for complete perchlorate removal (Figure 6). Perchlorate removal recovered only after decreasing influent DO levels to $1 \mathrm{mg} / \mathrm{L}$. These results raise questions regarding the extent by which shifts in specific microbial populations and changes in biofilm structure determine reactor performance and how reactor operation can be used to control such shifts. McCarty and Meyer (2005) applied a model to predict perchlorate removal based on the relative penetration of competing electron acceptors (oxygen, nitrate, and perchlorate) into biofilms. In their model, it was assumed that the appropriate bacteria (i.e., aerobic heterotrophic, denitrifying, and perchlorate reducing bacteria) establish themselves in different redox zones, and that perchlorate and nitrate removal are limited by the availability of electron donors rather than by the availability of appropriate bacteria. Our results agree with other studies in which reactor performance was not only determined by current operating conditions but also by the history of reactor operation (Kirisits et al., 2001; Wolf et al., 2005).

Further research should evaluate to what extent perchlorate reducing bacteria can establish themselves in a biofilm under optimal or suboptimal operating conditions.

\subsection{Scale up}

Glass beads are frequently used when a well defined and non-porous support medium is necessary for laboratoryscale biofilm reactor studies (e.g., Logan and LaPoint, 2002; Zhang and Huck, 1996). When interpreting results from such laboratory-scale systems, similarities and differences to full-scale systems need to be considered. In the current study, effluent perchlorate concentrations were similar to 
bulk phase concentrations in the reactors since recirculation of the effluent provided near completely mixed conditions in the bulk phase. Full-scale biofilm reactors are usually operated without recycling, which leads to concentration gradients along the length of the reactor. Whether backwashing results in complete mixing of the biofilm support media and avoid a heterogeneous distribution of biomass along the length of the reactor depends on factors such as reactor geometry and filter bed expansion during backwashing (Laurent et al., 2003). The completely mixed biofilm reactor used in the current study may not be representative of all types of fixed bed BAC reactors depending on mixing characteristics.

Suitable methods need to be developed to directly monitor biofilm growth and the accumulation of large microbial aggregates in filter media. In the current study, the significance of mass transfer limited zones is suggested based only on indirect inference. Large microbial aggregates were observed inside the reactors and during backwashing (Figure 2) and mass transfer limitations in such aggregates help to explain the observed perchlorate removal during periods with relatively high bulk phase DO concentrations. However, further studies are necessary to quantify the amount, distribution, and significance of these large microbial aggregates and their contribution to overall reactor performance.

Backwashing in the current study was performed after removing the reactor content from the reactor. The energy input and shear or abrasion forces during this backwashing procedure are different from those associated with backwashing in full-scale applications for which air scouring and increased water flow rates are typically used to expand the filter bed. However, the net result of backwashing, i.e., removal of the majority of the accumulated large microbial aggregates and a smaller fraction of the biofilm directly attached to the support medium, likely is similar in full-scale applications and in the current study (Laurent et al., 2003). Nevertheless, mixing conditions and backwashing of fixed bed biofilm reactors depend on scale and reactor geometry (Min et al., 2004) and mechanisms derived from laboratoryscale studies need to be evaluated further in pilot- and fullscale studies.

\section{Conclusions}

The effect of backwashing on perchlorate removal was studied in fixed bed biofilm reactors using 1- or 3-mm glass beads as support media. It was shown that:

- The response of fixed bed biofilm reactors to transient increases in influent DO levels depended on the history of backwashing. For an influent DO level of $3.5 \mathrm{mg} / \mathrm{L}$ and a slight electron donor deficit, no perchlorate removal was observed after strong backwashing, while the same influent conditions before backwashing resulted in $60 \%$ perchlorate removal. Presumably, the accumulation of large microbial aggregates resulted in local anaerobic zones that allowed for perchlorate reduction even with detectable DO concentrations in the bulk phase. Backwashing removed these aggregates and resulted in poor perchlorate removal in the presence of DO in the bulk liquid.
- The influence of backwashing on perchlorate removal depended on the electron donor to acceptor ratio in the influent. With electron donor addition in excess of stoichiometric requirements (3.2 times the stoichiometric requirement based on a net yield of $0.4 \mathrm{~g} \mathrm{COD}$ biomass $\mathrm{g} \mathrm{COD}_{\text {acetate }}$ ), strong backwashing resulted in a brief $(<12 \mathrm{~h})$ and small increase in effluent perchlorate concentrations. With the addition of electron donor close to stoichiometric requirement, perchlorate removal did not recover within $24 \mathrm{~h}$ after strong backwashing.

- The response to daily backwashing depended on the backwashing intensity. Weak daily backwashing had a small and, over time, decreasing negative effect on perchlorate removal. Strong daily backwashing had a substantial influence and ultimately lead to the complete breakdown of perchlorate removal.

- For practical applications, increasing the electron donor addition above the stoichiometric requirement would result in lower bulk phase DO concentrations, which would lead to more stable biofilm reactor performance following backwashing.

\section{Acknowledgements}

The authors would like to thank Vernon Snoeyink and Jess Brown for helpful discussions. This research was supported by the US National Science Foundation, Grant No. BES-0123342.

\section{References}

Ahmad et al., $1998 \rightarrow$ R. Ahmad, A. Amirtharajah, A. AlShawwa, and P. M. Huck, Effects of backwashing on biological filters, J. Am. Water Works Assoc. 90 (1998) (12), pp. 62-73.

APHA et al., 1999 APHA, AWWA, and WEF, Standard Methods for the Examination of Water and Wastewater (20th ed), American Public Health Association, Washington, DC, 1999.

Boller et al., 1997 M. Boller, D. Kobler, and G. Koch, Particle separation, solids budgets and headloss development in different biofilters, Water Sci. Technol. 36 (1997) (4), pp. 239-247.

Brown et al., $2002 \rightarrow$ J. C. Brown, V. L. Snoeyink, and M. J. Kirisits, Abiotic and biotic perchlorate removal in an activated filter, J. Am. Water Works Assoc. 94 (2002) (2), pp. 70-79.

Brown et al., 2003 J. C. Brown, V. L. Snoeyink, L. Raskin, and R. Lin, The sensitivity of fixed-bed biological perchlorate removal to changes in operating conditions and water quality characteristics, Water Res. 37 (2003) (1), pp. 206-214.

Brown et al., 2005 J. C. Brown, R. D. Anderson, J. H. Min, L. Boulos, D. Prasifka, and G. J. G. Juby, Fixed bed biological treatment of perchlorate-contaminated drinking water, J. Am. Water Works Assoc. 97 (2005) (9), pp. 70-81. 
Chaudhary et al., $2003 \rightarrow$ D. S. Chaudhary, S. Vigneswaran, H. H. Ngo, W. G. Shim, and H. Moon, Biofilter in water and wastewater treatment, Korean J. Chem. Eng. 20 (2003) (6), pp. 1054-1065.

Cohen and Metzner, $1981>$ Y. Cohen and A. B. Metzner, Wall effects in laminar-flow of fluids through packed-beds, AIChE J. 27 (1981) (5), pp. 705-715.

Delahaye et al., $1999 \rightarrow$ A. P. Delahaye, K. R. Gilmore, K. J.Husovitz, N. G.Love, T. Holst, and J. T. Novak, 1999. Distribution and characteristics of biomass in pilot-scale upflow biological aerated filters treating domestic wastewater. In: IWAQ Conference on Biofilm Systems, New York, October 17-20.

Giblin et al., $2000>$ T. Giblin, D. Herman, M. A. Deshusses, and W. T. Frankenberger, Removal of perchlorate in ground water with a flow-through bioreactor, J. Environ. Qual. 29 (2000) (2), pp. 578-583.

Henze et al., 2002 M. Henze, P. Harremoës, J. L. C. Jansen, and E. Arvin, Wastewater Treatment (third ed), Springer, Berlin (2002).

Herman and Frankenberger, 1999 D.C. Herman and W.T. Frankenberger, Bacterial reduction of perchlorate and nitrate in water, J. Environ. Qual. 28 (1999) (3), pp. 1018-1024.

Hozalski and Bouwer, 1998 R. M. Hozalski and E. J. Bouwer, Deposition and retention of bacteria in backwashed filters, J. Am. Water Works Assoc. 90 (1998) (1), pp. 71-85.

Kengen et al., 1999 S. W. M. Kengen, G. B. Rikken, W. R. Hagen, C. G. van Ginkel, and A. J. M. Stams, Purification and characterization of (per)chlorate reductase from the chlorate-respiring strain GR-1, J. Bacteriol. 181 (1999) (21), pp. 6706-6711.

Kim et al., 2004 H. S. Kim, P. R. Jaffe, and L. Y. Young, Simulating biodegradation of toluene in sand column experiments at the macroscopic and pore-level scale for aerobic and denitrifying conditions, Adv. Water Resour. 27 (2004) (4), pp. 335-348.

Kim and Logan, $2000-$ K. Kim and B. E. Logan, Fixed-bed bioreactor treating perchlorate-contaminated waters, Environ. Eng. Sci. 17 (2000) (5), pp. 257-265.

Kim and Logan, 2001 K. Kim and B. E. Logan, Microbial reduction of perchlorate in pure and mixed culture packedbed bioreactors, Water Res. 35 (2001) (13), pp. 3071-3076.

Kirisits et al., 2001 M. J. Kirisits, V. L. Snoeyink, H. Inan, J. C. Chee-Sanford, L. Raskin, and J. C. Brown, Water quality factors affecting bromate reduction in biologically active carbon filters, Water Res. 35 (2001) (4), pp. 891-900.

Lahav et al., 2001 O. Lahav, E. Artzi, S. Tarre, and M. Green, Ammonium removal using a novel unsaturated flow biological filter with passive aeration, Water Res. 35 (2001) (2), pp. 397-404.

Laurent et al., 1999 P. Laurent, M. Prevost, J. Cigana, P. Niquette, and P. Servais, Biodegradable organic matter removal in biological filters: Evaluation of the CHABROL model, Water Res. 33 (1999) (6), pp. 1387-1398.

Laurent et al., 2003 - P. Laurent, A. Kihn, A. Andersson, and P. Servais, Impact of backwashing on nitrification in the biological activated carbon filters used in drinking water treatment, Environ. Technol. 24 (2003) (3), pp. 277-287.
Lin, 2004 R. Lin, Bacterial community analysis and optimization of biologically active carbon filters used to remove perchlorate from groundwater. M.S. Thesis, Civil and Environmental Engineering, University of Illinois at UrbanaChampaign, 2004.

Liu et al., $2001-X$ X. B. Liu, P. M. Huck, and R. M. Slawson, Factors affecting drinking water biofiltration, J. Am. Water Works Assoc. 93 (2001) (12), pp. 90-101.

Logan and LaPoint, $2002>$ B. E. Logan and D. LaPoint, Treatment of perchlorate- and nitrate-contaminated groundwater in an autotrophic, gas phase, packed-bed bioreactor, Water Res. 36 (2002) (14), pp. 3647-3653.

McCarty and Meyer, 2005 P. L. McCarty and T. E. Meyer, Numerical model for biological fluidized-bed reactor treatment of perchlorate-contaminated groundwater, Environ. Sci. Technol. 39 (2005) (3), pp. 850-858.

Min et al., 2004 B. Min, P. J. Evans, A. K. Chu, and B. E. Logan, Perchlorate removal in sand and plastic media bioreactors, Water Res. 38 (2004) (1), pp. 47-60.

Nakhla and Farooq, $2003 \triangleright$ G. Nakhla and S. Farooq, Simultaneous nitrification-denitrification in slow sand filters, $J$. Hazard. Mater. 96 (2003) (2-3), pp. 291-303.

Niquette et al., 1998 P. Niquette, M. Prevost, R. G. Maclean, D. Thibault, J. Coallier, R. Desjardins, and P. Lafrance, Backwashing first-stage sand-BAC filters, J. Am. Water Works Assoc. 90 (1998) (1), pp. 86-97.

Servais et al., 1991 P. Servais, G. Billen, C. Ventresque, and G. P. Bablon, Microbial activity in Gac filters at the ChoisyLe-Roi treatment-plant, J. Am. Water Works Assoc. 83 (1991) (2), pp. 62-68.

Song, 2004 Y. Song, Respiratory pathways used by perchlorate respiring bacteria. Ph.D. Thesis, Pennsylvania State University, University Park, 2004.

Song and Logan, $2004>$ Y. G. Song and B. E. Logan, Effect of $\mathrm{O}_{2}$ exposure on perchlorate reduction by Dechlorosoma sp KJ, Water Res. 38 (2004) (6), pp. 1626-1632.

USEPA, 2006 USEPA, 2006. US Environmental Protection Agency Perchlorate Links; http://www.epa.gov/fedfac/ documents/perchlorate links.htm

Wanner et al., 2006 O. Wanner, H. J. Eberl, E. Morgenroth, D. R. Noguera, C. Picioreanu, B. E. Rittmann, and M. C. M. van Loosdrecht, Mathematical Modeling of Biofilms, IWA Publishing, London, UK (2006).

Wolf et al., 2005 G. Wolf, J. S. Almeida, M. A. M. Reis, and J. G. Crespo, Non-mechanistic modelling of complex biofilm reactors and the role of process operation history, J. Biotechnol. 117 (2005) (4), pp. 367-383.

Xu et al., 2003 J. L. Xu, Y. U. Song, B. K. Min, L. Steinberg, and B. E. Logan, Microbial degradation of perchlorate: principles and applications, Environ. Eng. Sci. 20 (2003) (5), pp. 405-422.

Zhang and Huck, 1996 S. L. Zhang and P. M. Huck, Parameter estimation for biofilm processes in biological water treatment, Water Res. 30 (1996) (2), pp. 456-464. 